\title{
変動プロペラ荷重を受ける船尾管軸受の油膜解析に関する研究* (コンテナ船による軸心軌跡計測結果と計算値の比較)
}

\author{
高橋定*1, 松本 將*2, 立石智 裕 ${ }^{* 3}$ \\ 大山賢二*4, 黒 岩良太 ${ }^{* 5}$, 諸星彰三*6
}

\author{
Study on Oil Film Analysis of the Stern Tube Bearing \\ Under the Conditions of Dynamic Propeller Shaft Forces \\ (Comparison Between Theory and Measurement Results \\ of Full-Scale Ship Propeller Shaft Center Loci)
}

\begin{abstract}
Sadamu TAKAHASHI ${ }^{* 7}$, Susumu MATSUMOTO, Tomohiro TATEISHI, Kenji OHYAMA, Ryota KUROIWA and Shozo MOROHOSHI

*7 The Graduate School of Information, Production and Systems, Waseda University, 2-7 Hibikino, Wakamatsu-ku, Kitakyushu-shi, Fukuoka, 808-0135 Japan
\end{abstract}

\begin{abstract}
This paper shows a new strong coupling analysis method for calculation of hydrodynamic lubricating film characteristics on the stern-tube-bearing of large-sized ships. The dynamic forces on the propeller shaft in turning conditions were calculated using CFD. Then, the propeller shaft center loci were calculated using dynamic propeller shaft forces, and were compared with the results of measurements of shaft center loci of a full-scale ship, where the results showed approximately good coincidence, thereby the validity of this analysis was confirmed.
\end{abstract}

Key Words : Stern Tube Bearing, Dynamic Propeller Shaft Force, Misalignment, Shaft Locus, Strong Coupling Method

\section{1. 緒 詥}

大型商船では，オーバハングしたプロペラ軸を船 尾管の油膜軸受で支持する構造が一般的に採用され, 図 1 に示す様な軸系配置となる.このため,プロペラ 自重, プロペラフォースの作用でプロペラ軸に大きな 曲げ撓みが生じ，船尾管軸受に片当たりが付く，通常， この様な片当たりはプロペラ軸のアライメント調整や スロープボーリング等の採用によって船尾管蟿受に損 傷が及ばないよう配慮される. しかし, アライメント 調整が不十分な場合, 油膜切れによる致命的軸受損傷 を招いてしまう。軸受損傷方止のためには，プロペラ 軸の曲げ撓みと軸受油膜との連成解析は極めて重要と

\footnotetext{
* 原稿受付 2009 年 5 月 20 日.

*1 正員, 早稲田大学大学院情報生産システム研究科 (\$ 808 0135 北九州市若松区ひびきの 2-7)

*2 正員, フェロー, 早䅧田大学大学院情報生産システム研究科.

*3 正員, 三菱重工業(株)長崎造船所(要 850-8610 長崎市飽の 浦町 1-1).

*4 三菱重工業 (株) 長崎造船所.

*5 三菱重工業(株) 技術本部長崎研究所(画 851-0392 長崎市哚 堀町 5-717-1).

*ä 正員, 長菱エンジニアリング(株) (恶 850-8610 長崎市飽の 浦町 1-1).

E-mail : s_takahashi@akane.waseda.jp
}

なり，また，実際の軸受損傷防止の観点から，船尾管 軸受に作用する荷重条件もプロペラ重量のみの静荷重 条件からプロペラ推進力によって生じるプロペラ動荷 重を考慮する必要が生じてきた。

船尾管軸受の解析に関するこれ迄の研究は以下の 状況である. 1960 年代に Asanabe (1) らによって船尾 管軸受特性に及ぼす片当たりの影響について研究が実 施され，実験と理論解析から片当たりと最小油膜厚さ の関係式等を導き出している. また，商船の大型化に 伴うプロペラ重量や軸アライメントが軸受油膜に及ぼ 寸影響については Ono (2) らの研究がある. その後, Saitoh ${ }^{(3)}$ 仕伴流によるプロペラフォースとプロペラ軸 の曲げ撓及を考慮した動的アライメント計算法につい て最初に提案し, 軸し軌跡の実船計㵋結果之計算結果 との比較を行った.

\section{Stern tube}

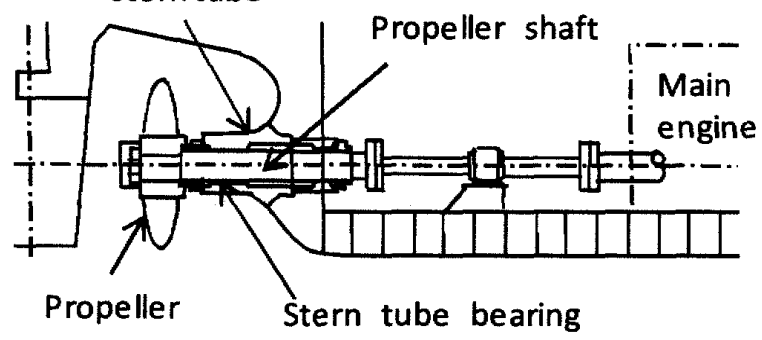

Fig. 1 Shatt arrangement 
また, Mitsui ${ }^{(}$はプロペラ低速回転時の重力方向荷 重を対象として船尾管軸受内でのプロペラ軸曲げ変形 と軸受油膜を連成させ超低速時の船尾管軸受油膜特性 を明らかにした. 更に, Marrelatos (5) はプロペラ軸 の曲げ撓みと軸受メタルの弾性変形を同時加味した解 析方法を示し, 軸受モデル試験結果の油膜王力分布と 比較して良く一致する結果を得ている。一方， Saki (6) は二重反転プロペラ用船尾管軸受の研究で大きな 片当たりを生じるプロペラフォースが作用する場合の 軸受油膜特性解析法を検討し, 油膜可転云ね゙の考えを 導入することで反復計算の収束性改善を行い，二重反 転プロペラを採用した超大型船での軸し軌跡計測結果 と比較し解析結果の有效性を示した. 以上は，プロペ ラフォースが変動しない定常荷重条件での結果である が, Karmi (7) は Mourelatos ${ }^{(5)}$ の研究に続いてプロペ ラ軸の運動万程式と船尾管軸受の油膜特性を連成させ 時刻歷解析法を示し RO-RO 船 (Rollon Roll-off vessel) を対象に正弦波状に変動するプロペラ荷重が作用した 場合の油膜解析を行った。

ところで，船尾管軸受にとつて高速での旋回操船 は最も油膜が薄くなる過酷な条件であるが，これまで， 高速旋可過程の油膜解析と実船での軸心計測結果とを 比較検討した報告例はほとんど見あたらない：これは， 旋回操船が伴流の過渡現象を伴うためプロペラフォー スの高精度予測が難しいことと，斜流によるモーメン 卜荷重の増大でプロペラ軸が大きく撓み，片当たりが 強くなり油膜解析上の收束計算が困難になってしまう ためと推定される. しかしながら, プロペラフォース に関しては, 最近の CFD の発達とプロペラ単体によ る水槽試験での計測技術の向上によって推進性能予測 とともに軸受に作用するプロペラフォースの予測精度 は著しく向上してきた. また，船尾管軸受油膜特性と プロペラ軸撓みとの連成問題は， EHL 解析に見られ るように弾性変形とレイノルズオ程式を連成させた強 連成問題として扱うことで収束性の改善が期待できる. 本報告は，著者らの一人により示された高速旋回時 の変動プロペラフォース予測解析法》を用い，船尾 管軸受油膜とプロペラ軸墝みの連成問題の收束性改善 によって旋回時の変動荷重による油膜解析を実施し, 実船計測值と比較検討した結果について述べる.

\section{2. おもな記号}

\section{$F:$ プロペラフォース $[\mathrm{kN}]$ \\ $M:$ モーメント [kN-m] \\ $W(\xi)_{z}: \mathrm{Z}$ 力向蟿受支持点反力 $[\mathrm{kN}]$}

$W(\xi) y: Y$ 力向軸受支持点反力 $[\mathrm{kN}]$

$M z: \mathrm{Z}$ 軸回り油膜反力モーメント $[\mathrm{kN}-\mathrm{m}]$

$M y: \mathrm{Y}$ 軸回り油膜反力モーメント[kN-m]

$D:$ 軸受直径 $[\mathrm{mm}]$

$C r:$ 軸受半径隙間 $[\mathrm{mm}]$

$R:$ 軸受半径 $[\mathrm{mm}]$

$U:$ すべり速度 $[\mathrm{mm} / \mathrm{sec}]$

$\mu o:$ 潤滑油粘度 [Pa·s]

$p$ : 油膜王力 $[\mathrm{Pa}]$

$h:$ 油膜厚さ $[\mathrm{mm}]$

$h e:$ 真円からの軸受すき間のずれ $[\mathrm{mm}]$

$e_{z}: Z$ 方向軸受偏心量 $[\mathrm{mm}]$

$\theta: \mathrm{Y}$ 方向輷偏心量 $[\mathrm{mm}]$

$\xi z: Z X$ 面内軸受支持点位置 [mm]

$\xi y$ : Y-X 面内軸受支持点位置 [mm]

$\alpha z: \mathrm{Z}$ 軸回りのプロペラ軸傾き [rad]

$\alpha_{y}: \mathrm{Y}$ 軸回りのプロペラ軸傾き [rad]

$\delta \mathrm{p}$ : 修正油膜圧力 $[\mathrm{Pa}]$

$\delta \mathrm{e}:$ 修正偏心量 $[\mathrm{mm}]$

$\delta \xi$ : 修正支持点位置 [mm]

$\omega:$ 重み係数

$\Omega:$ 積分範进

$\xi_{Z Y}:$ 仮想軸受支持点 $[\mathrm{mm}]$

$\Delta t:$ 時間刻み [sec]

$x y, z$ : 座標軸

$\theta:$ 軸受円周力向座標

\section{3. プロペラ軸と軸受の連成解析方法の改善}

従来の定常油膜解析法では，まず，図 2 (a)に示寸様 にプロペラ軸系を連続梁でモデル化する．次に，船尾 管軸受の幅方向中央付近に単純支持点を設け，プロペ ラ位置にプロペラフォースを加え船尾管軸受位置の支 点反力を求める. そして，軸受油膜反力がこの支点反 力と 致するよう軸受油膜解析にて軸心偏心量を調整 する，ただし，軸受はプロペラ軸の曲げ撓みによって 片当たりを生じているため片当たり状態て軸受油膜反 力と支点反力の 致が必要になる. なお, 片当たりの 発生は油膜反力モーメントを誘起し，プロペラ軸の片 当たりを緩和しようとする復元性を生み出す．したが って, 油膜反力モ一メントを加味することで厳しい軸 受荷重条件でも油膜成立の数值解が得られ，Sak的ら はこの油膜反力モーメントの作用を油膜回転ばねで表 現し二重反転プロペラ用軸受で高速旋回時の定常油膜 解析を実施している. 
ところで，油膜反力モーメントはプロペラ軸の軸受 支点位置傾きの大きさに依存し，他力，プロペラ軸の 軸受支点位置傾きの大きさは，油膜反力モーメントに 関係している.これまで両者の釣合状態の求め力には, それぞれを独立して解き，それらの解を交互に受け渡 し許容誤差内に收束するまで反復させる弱連成法が採 用されている。しかし，軸受油膜特性は非線形である ため，荷重の釣り合いも同時に満足させ得る収束解を 見つけることは簡単ではない，そこで，本報告では図 2 (b)に示すように軸系モデルにおいて船尾管蟿受の幅 方向中央位置に支持点を固定せず，同位置を未知数と 考え油膜反力モーメントとプロペラ軸片当たりの関係 を非連成化した．つまり，軸受油膜圧力分布を円周方 向に積分し軸办向線圧分布とした時, その重心位置 (線圧モーメントバランス位置) を支持点と見なすこ とで, 支持点回りの油膜反力モーメントが消去できる ことになる. なお，代わりに支持点位置と軸受荷重が 末知数に加わるが，支持点が決まれば何重も決まるた め, 軸受荷重を支持点の関数で表現し收束性改善を図 った.

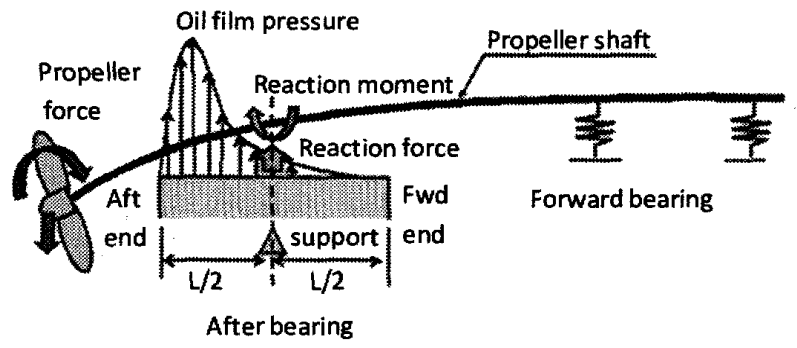

(a) Conventional analysis model of a shafting system

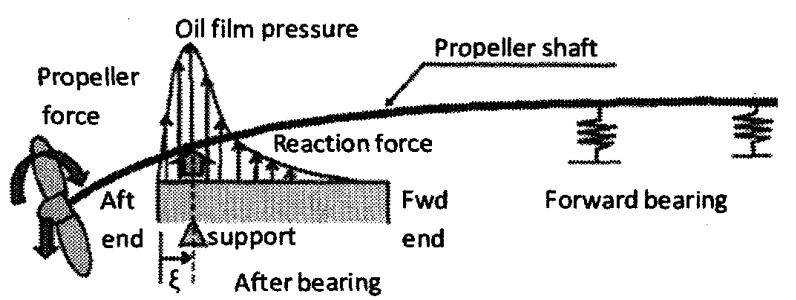

(b) New conoeptanalysis model of a shafting system

Fig. 2 Shatting system analysis model

\section{3・1 レイノルス方程式と軸系抏みの連成}

船尾管軸受のレイノルズす程式を式(1)に示す，そし て, Z 軸力向荷重釣り合いを式(2)，Y 軸力向の荷重 釣り合いを式(3)に示寸.

$$
f_{1}=\nabla\left(e^{-\alpha p} h^{3} \nabla p\right)-12 \mu_{0}\left(\frac{U}{2} \frac{\partial h}{R \partial \theta}+\frac{\partial h}{\partial t}\right)=0 \text { (1) }
$$

$$
\begin{aligned}
& f_{2}=\int_{\Omega} p(-\cos \theta) d \Omega-W_{(\xi) z}=0 \\
& f_{3}=\int_{\Omega} p(-\sin \theta) d \Omega-W_{(\xi) y}=0
\end{aligned}
$$

ここで, 荷重 $W(\xi)$ は軸受内仮想支持位置 $\xi$ 点の 関数であり時刻䄳で変動する. 次に, 支持位置 $\xi$ 点に おける油膜モーメントの釣り合いは, Z-X 平面の $\mathrm{Y}$ 軸回り油膜モーメントがゼロ，Y-X 平面の軸 Z回り油 膜モーメントがゼロであるとの必要条件から式(4), 式(5)を得る.

$$
\begin{aligned}
& f_{4}=\int_{\Omega}\left\lfloor p(-\cos \theta)\left(\xi_{Z}-x\right) d \Omega-M_{y}\right\rfloor=0 \\
& \left.f_{5}=\int_{\Omega} \mid p(-\sin \theta)\left(\xi_{y}-x\right) d \Omega-M_{Z}\right\rfloor=0
\end{aligned}
$$

ただし，この場合，My，MEはゼロである．また，軸 受の座標系を図 3 に示寸. 油膜摹さ $h$ は, プロペラ軸 の片当たり $a Z, a Y$ 並びに任意軸受寸きま間分布を考 慮するため真円すき間形状からの軸受すき間変化 he を加え式(6)で表した。

$$
\begin{aligned}
h=c_{r} & -\left[e_{Z}-\alpha_{y}\left(\xi_{z}-x\right)\right] \cos \theta \\
& -\left[e_{y}+\alpha_{Z}\left(\xi_{y}-x\right)\right] \sin \theta+h e
\end{aligned}
$$

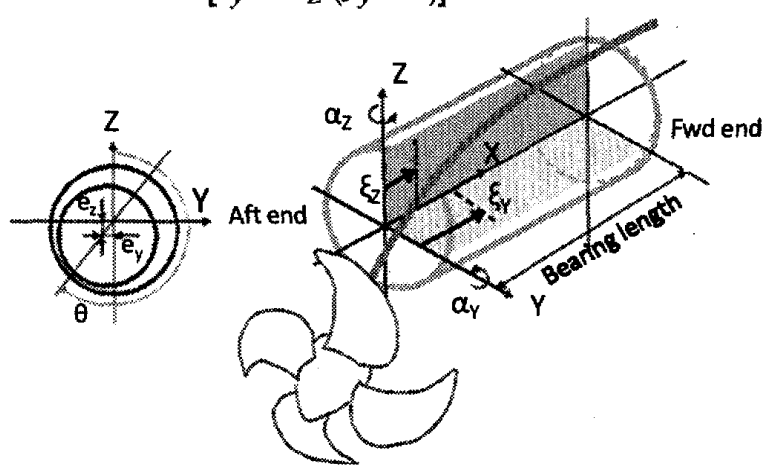

Fig. 3 Bearing geometry

以上の式(1)から式(5)に Newton-Raphson 法を適用す ると式(すを得る．ただし，右肩添字 $\mathrm{n}$ は反復回数を 示し， $\mathrm{n}$ 回目が既知， $\mathrm{n}+1$ 回目が末知である.

$$
\begin{aligned}
f_{i}^{n+1}= & f_{i}^{n}+\left(\frac{\partial f_{i}}{\partial p}\right)^{n} \delta p^{n} \\
& +\left(\frac{\partial f_{i}}{\partial e_{z}}\right)^{n} \delta e_{Z}^{n}+\left(\frac{\partial f_{i}}{\partial e_{y}}\right)^{n} \delta e_{y}^{n} \\
& +\left(\frac{\partial f_{i}}{\partial \xi_{z}}\right)^{n} \delta \xi_{Z}^{n}+\left(\frac{\partial f_{i}}{\partial \xi_{y}}\right)^{n} \delta \xi_{y}^{n}
\end{aligned}
$$


そして，式(7)をマリックス表示すると次式となる.

$$
\left[\begin{array}{l}
\mathrm{A} \\
\Delta \mathrm{e} \\
\Delta \xi
\end{array}\right\}=\left\{\begin{array}{l}
\Delta \mathbf{p} \\
\operatorname{Re} \\
\mathbf{R} \xi
\end{array}\right\}
$$

ここで,

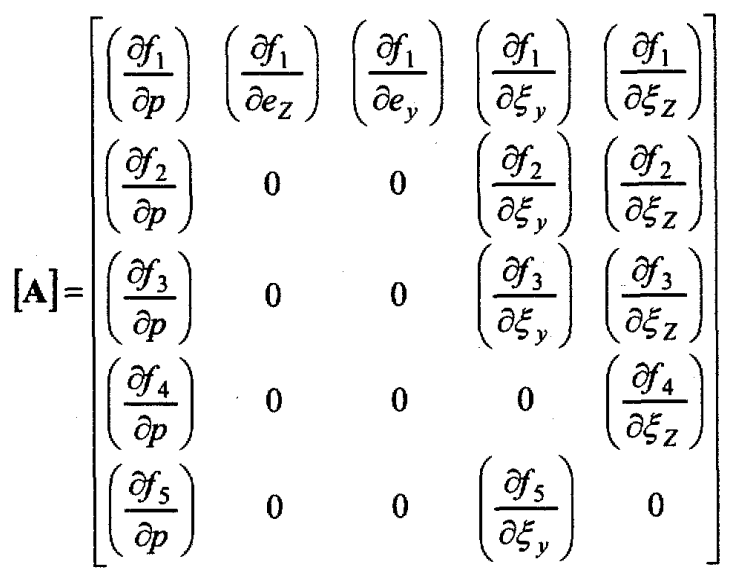

(9)

$$
\begin{gathered}
\left\{\begin{array}{l}
\Delta \mathbf{p} \\
\Delta \mathbf{e} \\
\boldsymbol{\Delta} \xi
\end{array}\right\}=\left\{\begin{array}{l}
\delta p \\
\delta e_{Z} \\
\delta e_{y} \\
\delta \xi_{y} \\
\delta \xi_{Z}
\end{array}\right\} \\
\left\{\begin{array}{l}
\mathbf{R p} \\
\mathbf{R e} \\
\mathbf{R} \xi
\end{array}\right\}=\left\{\begin{array}{l}
R_{p}=f_{1}^{n} \\
R_{w z}=f_{2}^{n} \\
R_{w y}=f_{3}^{n} \\
R_{m y}=f_{4}^{n} \\
R_{m z}=f_{5}^{n}
\end{array}\right\}
\end{gathered}
$$

ところで, 式(1)の解法には重み付き残差法を適用した。 従って, 式(9)の右辺マトリックス要素に現れる微分倸 数は重み係数を $\omega$ として次式の通り表される.

$$
\begin{aligned}
& \frac{\partial f_{1}}{\partial p} \delta p=\int_{\Omega} \nabla \omega\left(\alpha \delta p e^{-\alpha p} h^{3} \nabla p\right) d \Omega \\
& -\int_{\Omega} \nabla \omega\left(e^{-\alpha p} h^{3} \nabla \delta p\right) d \Omega \\
& \frac{\partial f_{1}}{\partial e_{Z}} \delta e_{Z}=-\int_{\Omega} \nabla \omega\left(e^{-\alpha p} 3 h^{2} \cos \theta \nabla p\right) \partial e_{Z} d \Omega \\
& -\int_{\Omega} \omega\left[12 \mu_{0}\left(\frac{U}{2} \frac{\sin \theta}{R}\right)\right] \dot{\delta} e_{Z} d \Omega \\
& -\int_{\Omega} \omega\left[12 \mu_{0} \frac{\partial}{\partial e_{Z}}\left(\frac{\partial h}{\partial t}\right)\right] \dot{\partial e_{Z}} d \Omega
\end{aligned}
$$

$$
\begin{aligned}
\frac{\partial f_{1}}{\partial e_{y}} \delta e_{y}= & -\int_{\Omega} \nabla \omega\left(e^{-\alpha p} 3 h^{2} \sin \theta \nabla p\right) \delta e_{y} d \Omega \\
& -\int_{\Omega} \omega\left[12 \mu_{0}\left(-\frac{U}{2} \frac{\cos \theta}{R}\right)\right] \delta e_{y} d \Omega \\
& -\int_{\Omega} \omega\left[12 \mu_{0} \frac{\partial}{\partial e_{y}}\left(\frac{\partial h}{\partial t}\right)\right] \delta e_{y} d \Omega
\end{aligned}
$$

$$
\begin{aligned}
\frac{\partial f_{1}}{\partial \xi_{y}} \delta \xi_{y} & =-\int_{\Omega} \nabla \omega\left(e^{-\alpha p} 3 h^{2} \frac{\partial h}{\partial \xi_{y}} \nabla p\right) \delta \xi_{y} d \Omega \\
& -\int_{\Omega} \omega\left[12 \mu_{0} \frac{U}{2} \frac{\partial}{\partial \xi_{y}}\left(\frac{\partial h}{R \partial \theta}\right)\right] \delta \xi_{y} d \Omega \\
& -\int_{\Omega} \omega\left[12 \mu_{0} \frac{\partial}{\partial \xi_{y}}\left(\frac{\partial h}{\partial t}\right)\right] \delta \xi_{y} d \Omega
\end{aligned}
$$

なお, 式(15)右辺の $\xi_{y}$ に関する微分は式(16)のとおり

$$
\begin{aligned}
& \frac{\partial h}{\partial \xi_{y}}=\left(\alpha_{Z}+\xi_{y} \frac{\partial \alpha_{Z}}{\partial \xi_{y}}\right)(-\sin \theta) \\
& \frac{\partial}{\partial \xi_{y}}\left(\frac{\partial h}{R \partial \theta}\right)=\left(\alpha_{Z}+\xi_{y} \frac{\partial \alpha_{Z}}{\partial \xi_{y}}\right) \frac{-\cos \theta}{R} \\
& \frac{\partial}{\partial \xi_{y}}\left(\frac{\partial h}{\partial t}\right)=\left(\alpha_{Z}+\xi_{y} \frac{\partial \alpha_{Z}}{\partial \xi_{y}}-\alpha^{\text {old }}{ }_{Z}-\xi^{\text {old }}{ }_{y} \frac{\partial \alpha^{\text {old }} z}{\partial \xi^{\text {old }}}\right) \\
& \times\left(\frac{-\sin \theta}{\Delta t}\right)
\end{aligned}
$$

また， $\xi_{Z}$ に関する微分係数は式(15)の $\xi_{y}$ を $\xi_{Z}$ に入 れ替えた表示となる. 残りの微分係数は次式となる.

$$
\begin{aligned}
& \frac{\partial f_{2}}{\partial p} \dot{\phi}=\int_{\Omega} \delta p(-\cos \theta) d \Omega \\
& \frac{\partial f_{3}}{\partial p} \delta p=\int_{\Omega} \delta p(-\sin \theta) d \Omega \\
& \frac{\partial f_{4}}{\partial p} \delta p=\int_{\Omega}\left[\delta p(-\cos \theta)\left(\xi_{Z}-x\right)\right] d \Omega \\
& \frac{\partial f_{5}}{\partial p} \delta p=\int_{\Omega}\left[\dot{\phi}(-\sin \theta)\left(\xi_{y}-x\right)\right] d \Omega
\end{aligned}
$$




$$
\begin{aligned}
& \frac{\partial f_{3}}{\partial \xi_{y}} \delta \xi_{y}=-\frac{\partial W_{(\xi) y}}{\partial \xi_{y}} \\
& \frac{\partial f_{3}}{\partial \xi_{Z}} \delta \xi_{Z}=-\frac{\partial W_{(\xi) y}}{\partial \xi_{Z}} \\
& \frac{\partial f_{4}}{\partial \xi_{Z}} \delta \xi_{Z}=W_{Z c a l} \\
& \frac{\partial f_{5}}{\partial \xi_{y}} \delta \xi_{y}=W_{y c a l}
\end{aligned}
$$

ここで, 式(20)の右辺はそれぞれ Z 力向，Y 方向の油 膜反力計算值を表寸. 更に, 式(11)の残差項の内, レ イノルズカ程式に関する残差項 $R p=f_{1} n$ は式(21)の 通りである.

$$
\begin{aligned}
R p= & f_{1}^{n}=\int_{\Omega} \nabla \omega\left(e^{-\alpha p} h^{3} \nabla p\right) d \Omega \\
& +\int_{\Omega} \omega\left[12 \mu_{0}\left(\frac{U}{2} \frac{\partial h}{R \partial \theta}\right)\right] d \Omega \\
& +\int_{\Omega} \omega\left[12 \mu_{0}\left(\frac{\partial h}{\partial t}\right)\right] d \Omega
\end{aligned}
$$

荷重の残差項 $R w$ とモーメントの残差項 $R m$ は式(2)か ら式(5)により明らかであるため表示を割懓した。

方，軸系たわみ計算では，仮想支点 $\xi$ 位置での軸 受反力, 軸の傾きを求めることになる.この時, 旋回 時のプロペラフォースは変動荷重であるため, 本来は プロペラ軸系の運動方程式に基づき時刻歴応答解析が 必要である. しかし, 大型商船の旋回試験では, 後述 する様にプロペラフォースの変動速度が遅い.このた めプロペラ軸系の曲げ 1 次固有振動数から離れた領域 での応答となり慣性力の影響は少ない：この様な場合， プロペラ軸系の振る舞いは静的扱いで実用上問題ない ためここでは剛性法による連続梁計算を実施した。

\section{2 数值計算法 レイノルズ力程式の解法} に用いた重み付き残差法には Galerkin 法を使用し， 離散化には有限要素法を適用した，また，軸受面要 素に使用した形状関数は線形 1 次とし, 油膜厚さ $h$ の時間微分は後退差分で離散化した。 ところで, 軸受油膜と軸撓みを連成させた式 (8) は非線形であ るため, 油膜圧力や偏心量, 支点位置の解を得るに は反復計算が必要になる。このため, 最初, 油膜圧 力や偏心量，支点位置を仮定し，この仮定值に基づ き式 (8) を解き修正油膜圧力 $\delta \mathrm{p}$, 修正偏心量 $\delta \mathrm{e}$, 修正仮想支点位置 $\delta \xi$ 求める.こうして得られた修 正油膜圧力 $\delta \mathrm{p}$, 修正偏心量 $\delta \mathrm{e}$, 修正仮想支点位 置 $\delta \xi$ は仮定した油膜圧力や偏心量, 仮想支点位置
が仪束解であればぜロに近い．収束解でなければ式 (22)により新たに油膜圧力や偏心量，仮想支点位置 を仮定して再び式 (8) を解く.この操作を繰り返し 実施し空間領域での収束解を求め, 次の時間ステッ プに移る.

$$
\begin{aligned}
& p^{n+1}=p^{n}+\delta p^{n} \\
& e_{Z}^{n+1}=e_{Z}^{n}+\delta e_{Z}^{n} \\
& e_{y}^{n+1}=e_{y}^{n}+\delta e_{y}^{n} \\
& \xi_{Z}^{n+1}=\xi_{Z}^{n}+\delta \xi_{Z}^{n} \\
& \xi_{y}^{n+1}=\xi_{y}^{n}+\delta \xi_{y}^{n}
\end{aligned}
$$

ただし，Newton-Raphson 法は 2 次精度であるが， 軸墝みが大きく片当たりの強い場合は式(21)を用いて も收束解を得ることが困難になる.この様な場合は初 期の仮定値を変える，時間刻みを細かくする等で妀束 解を得ることができる. また，軸受面のキャビテーシ ヨン領域は Newton-Raphson 法の繰り返しループの中 で式(22)により修正された圧力，偏心量を用いて式(1) からその都度判定した. 即ち, 式(1)が負となる軸受面 要素節点の油膜圧力はゼロに置き換えた.

\section{4. コンテナ船での油膜計測結果との比較}

本解析法の有効性確認のため，実船計測された船尾 管軸受の軸心軌跡計測結果との比較を行う。計測対象 の船は全長 $262 \mathrm{~m}$ ，幅 $40 \mathrm{~m}$ ，深さ $24.3 \mathrm{~m}$ の大型コンテ 十船で, 最大出力 66,120 馬力, 最大船速 28 knots で ある. また，プロペラ外径は $8.3 \mathrm{~m}$. プロペラ重量 66ton, 軸直径 $960 \mathrm{~mm}$ の -軸推進系で定格回転数は $\mathrm{N}=102$ rpm ある. プロペラ軸を支える軸受は直径 $D=960 \mathrm{~mm}$ ，軸受長さ比 $L D=2$, 軸受直径すき間比 $C D=0.0015$ である。また、軸受には約 $0.01 \mathrm{deg}$ のスロ ープボーリングが施され、ホワイトメタルでライニン グしている. 使用している潤滑油は VG100 相当の鉱 物油で試運転時の軸受給油温度は $34^{\circ} \mathrm{C}$ C゙あった.

4.1 プロペラフォースの推定 様々な船の 運航状態の内, 船尾管軸受にとって最も油膜厚さが 薄くなり損傷の危険性が高い過酷な条件は試運転時 に行われる連続最大出力での操舵角 $\pm 35 \mathrm{deg}$ の旋回 試験である，旋回時に油膜厚さが薄膜化するこの理 由は，転舵に伴いプロペラには斜め横から強い流れ が入り，プロペラ面流場が著しく不均 一となる。 こ の結果, 図 4 に示寸样にプロペラ軸を横に曲げよ うとするプロペラフォース $M_{Z}\left(K M_{Z}\right.$ : 無次元值 $)$ と下方に曲げようとする $M y(K M y$ : 無次元值) が 
発生し，軸受への片当たりを増大させるためである 転舵時のプロペラフォースは不均 流場が発生原因 であるため, 船尾形状, プロペラ軸数などの影響が 大きく, 従来, プロペラ単体での水槽模型試験とプ ロペラ揚力面理論を用いたプロペラ性能計算法によ り定常プロペラフォースを予測していた.

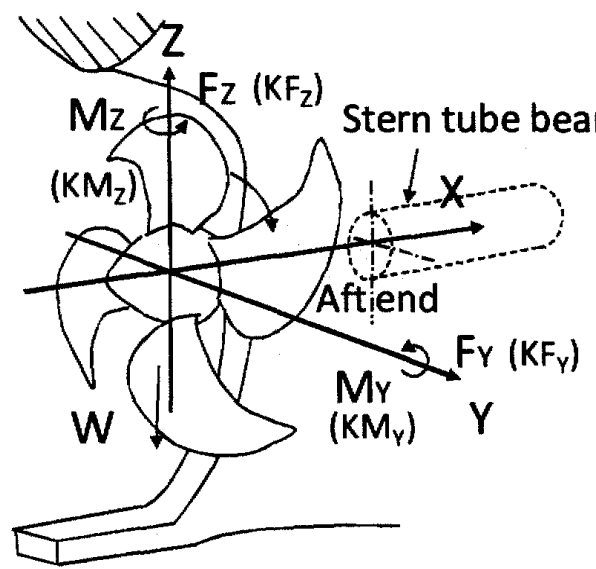

Fig. 4 Hydrodynamic forces acting on propeller

これに対し, 最近, kumiwa ${ }^{(8)}$ らは 3 次元 CFDに よるプロペラ面流場推定により，旋回時のプロペラフ オースを時刻歴で予測する手法を開発した。この手法 を用い回転数, プロペラ直径, 海水密度から式(23)で 無次元したプロペラフォース予測值を表 1 と図 5 に示 す.ここで、表 1 は定常状態の最大プロペラフォース である。図 5 は右旋回 $35 \mathrm{deg}$ 時と左旋回 $35 \mathrm{deg}$ 時の プロペラフォースを時刻䄳で示したものである. 表 1 の結果から，旋回時の定常プロペラフォースは直進時 に比べ $K M_{z}$ が著しく増加している. そして， $K F_{y}$ も $50 \%$ 程度增えているため両者の影響で船尾管軸受の左 舷側は強く片当たりする傾向が出る．また，時刻歷で みると $K M E ， K F_{y}$ 共に転舵操作方完了する 30 秒程で 緩やかなピーク值を示しその後徐々低下している.

$$
\begin{array}{ll}
K F_{Y}=\frac{F_{Y}}{\rho N^{2} D_{p}^{4}} & K F_{Z}=\frac{F_{Z}}{\rho N^{2} D_{p}^{4}} \\
K M_{Y}=\frac{M_{Y}}{\rho N^{2} D_{p}^{5}} & K M_{Z}=\frac{M_{Z}}{\rho N^{2} D_{p}^{5}}
\end{array}
$$

Table 1 Estimated non-dimensional propellerforces

\begin{tabular}{|c|c|c|c|c|}
\hline & $K F_{Y}$ & $K F_{Z}$ & $K M_{Y}$ & $K M_{Z}$ \\
\hline $\begin{array}{c}\text { Straight } \\
\text { ahead }\end{array}$ & -0.0083 & 0.0077 & -0.0092 & 0.0053 \\
\hline $\begin{array}{c}\text { Right } \\
\text { turn with } \\
\text { 35deg }\end{array}$ & 0.012 & -0.017 & 0.0051 & -0.0087 \\
\hline $\begin{array}{c}\text { Left turn } \\
\text { with } \\
\text { 35deg }\end{array}$ & -0.014 & -0.022 & -0.0082 & -0.0091 \\
\hline
\end{tabular}

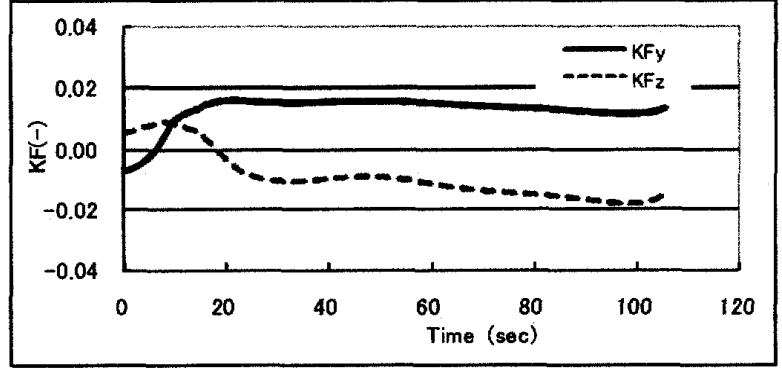

(a) Propeller forces under right tum 35 deg condition

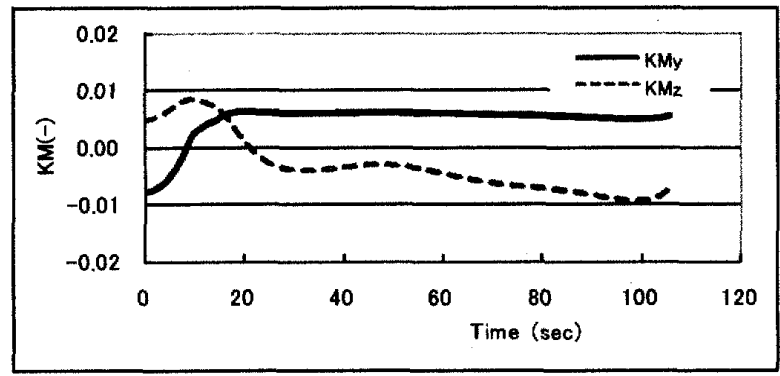

(b) Propeller moments under right turn 35 deg condition

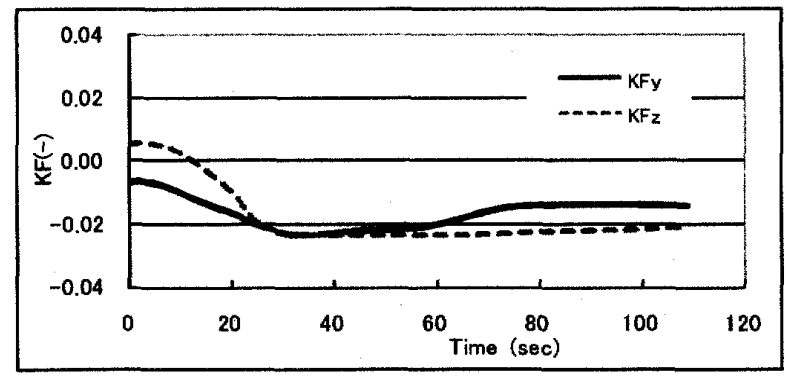

(c) Propeller forces under left tum 35deg condition

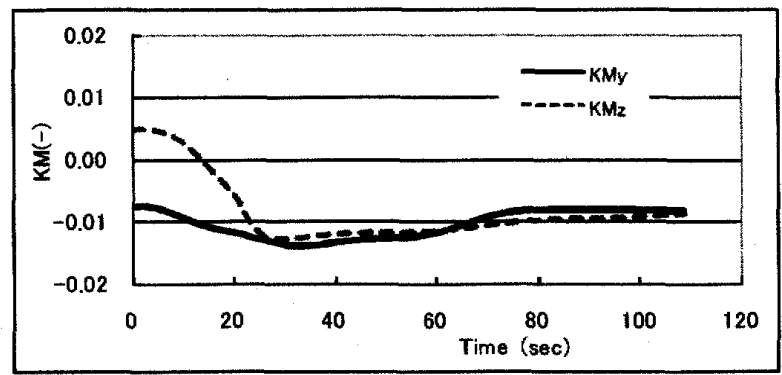

(d) Propeller moments under left tum 35deg condition Fig. 5Non-dimensional propeller shaft forces during turning

\section{$4 \cdot 2$ 計算值と実測値の轴心軌跡比较桔果}

4.2.1 直進条吽での比較 最大船速による 直線航行での軸心計算值と実測值の比較を図 6 に 示寸.ここで, 軸心位置の計測は船尾管軸受の AFT 端面と FWD 端面に渦電流式変位計を直角力 向に 2 個ずつ計 4 個取付け計測したものである. 
また，計算值は定常計算である.この結果，計算伹 と実測值は良く 致していることが分かる. なお， 船尾管軸受 AFT 端側の軸心は，軸受中心から上部 側のやや左舷寄りに，そして軸受 FWD 端側は下部 側の左舷奇り位置している，これは，Fzでプロペ ラ軸が持ちあがり，My で更に上方向に曲げられる ためである. また， $M z$ で右舷側に曲げられようと するが， Fy で左舷側に奇せられ全体として左舷側 寄りになったものである.この様な直進時において 軸心が軸受中心付近に位置する事例は saitho(ららの 報告にも示されている.
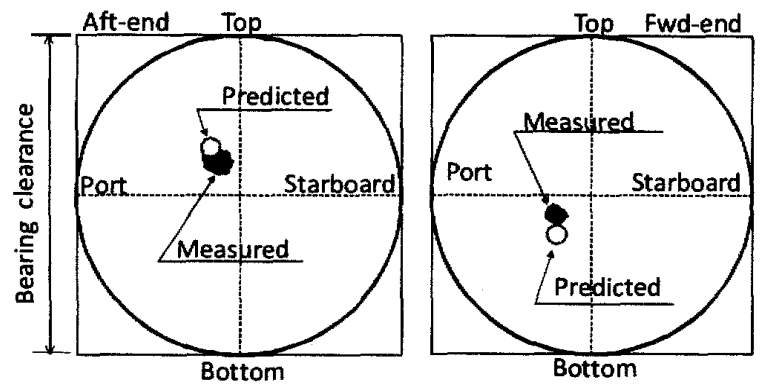

Fig. 6 Shaft œenter locus under steady ahead condition

\subsection{2 旋回条件での比较 35deg 旋回時の} 軸受油膜特性に関する報告例は，二重反転プロペラ を対象にした Saki ${ }^{(9)}$ らの研究に認められるものの， 旋回時の時刻歴軸受油膜計算報告例は見あたらない， これは，プロペラ軸の曲げ撓みと油膜軸受の非定常 連成計算手法が確立されていなかったためである.

そこで，第 3 章で述べた本解析手法を用い旋回時 の時刻歴軸受油膜計算を行った. 最初, 時間刻みを 2 秒で開始し途中荷重変化が緩やかな時刻からは 10 秒刻みに増やした。

船尾管軸受 AFT 端位置での右 35deg 旋回時の軸 心軌跡実測俻と計算值の比較を図 7 に示す。なお, 旋回で船体は 10deg から 20deg 前後傾斜するため 変位センサーの取付け座標が重力方向からずれる. 実測值はそのずれを補正し表示した. 実測值の軸心 位置は軸受すき間円の中央付近下すからスタートし， 旋回の進行と共に右舷側下力向に沈み，旦軸受下 面を右舷力向に移動し, その後, 逆に左舷側に向か って軸受下面沿いを駆上っている．続いて計算結 果を○印で示寸，スタート位置は実測㥀よりやや上 の軸受中心付近にある。しかし，旋回が進むに従い 軸心は右舷側下力向に移動する．そして・旦軸受下 面に近づいた後は軸受下面を這うように左舷側に向 かって駆け上がる仇跡を示し，概ね実測值と傾向が 致している.

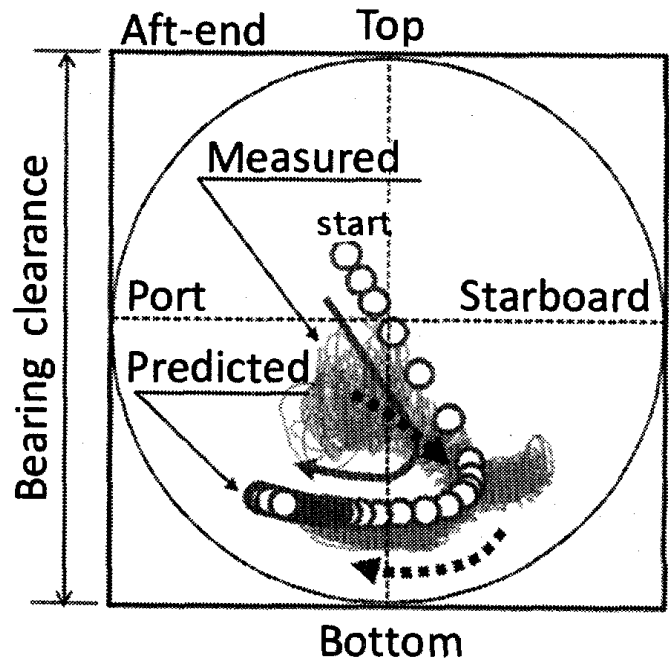

Fig. 7Shaftcenter locus during right tum condition

次に，左 35deg 旋回時の結果を図 8に示寸。図中○ 印が計算結果、実線が実測結果のリサージュである. 実測值のリサージュが重なっているが，スタート時点 の軸心は軸受中心より上方向にあり、そこから軸受面 に沿って左舫側に接近している．しかし，極端に左舷 側に近接することなく，軸受下方に向かいながら左舷 側軸受面から離れていく傾向を示す。これに対して, 計算伯のスタートは軸受中心付近に軸心があり，そこ から旋回の進行之共に一旦左舫側上力向に向かった後, 緩やかに下力向に移動しながら左舷側に最接近し最小 油膜厚さとなる，その後は時間経過と共に左舷側軸受 面に沿って軸受下力向に移動しながら油膜回復してい る.この様に軸心軌跡の傾向としては計算値と実測值 は概子符合している.

なお，図 6，図 7 ともに AFT 側から見た軸心軌跡 であり,プロペラ軸は時計回りに回転している.

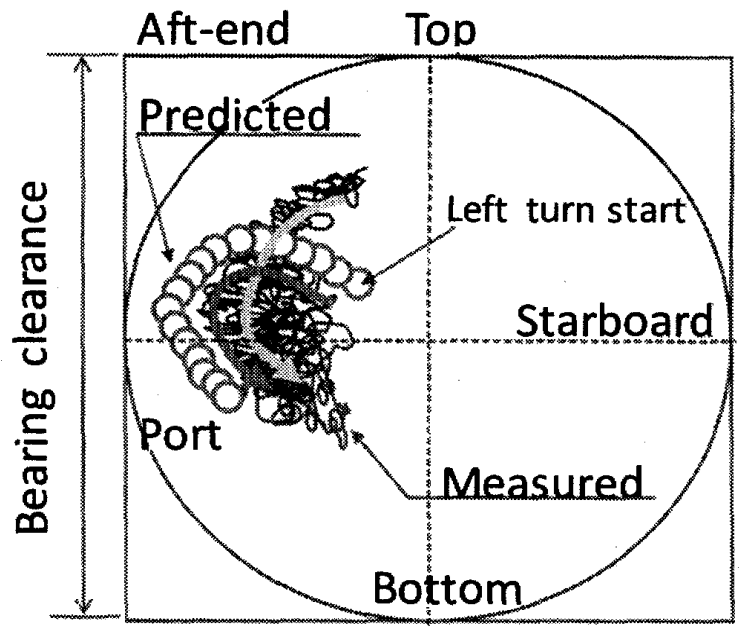

Fig. 8 Shaftcenter bocus during left turn condition 


\section{5. 考宗}

左 $35 \mathrm{deg}$ 旋回時の実測值はリサージュが幾重にも 重なって見え，そのリサージュ幅は回転数が同じ直進 時と比べかなり広い:このことから，左旋回では約士 $100 \mu \mathrm{m}$ 前後の振幅で蟿振動が発生していたものと思 われる.この軸振動の発生限はプロペラ 1 枚每に生じ る 1 回転中の翼面変動圧力と推察される. 発生する変 動周波数はプロペラ枚数に応じた高周波数成分を持つ ため，暉受面のスクイズ効果で油膜厚さは厚くなる. つまり，計算值か溥く，実測值が厚く生じた左旋回の 最小油膜厚さは，この高周波数の変動成分が原因と思 われる. 才, 右旋回の場合, 油膜が薄い位置でリサ 一ジュの重なり幅が狭く，高周波の変動荷重は小さか ったものと推走され，これが計算俻と実測值で比較的 良く一致した理由と思われる.

ところで，実測した右旋回の軸心軌跡が軸受下面を 一旦右舷側に少し移動した後で左舷側一反転している ことに対し，軸受形状にその要因と考えられるものは 見あたらず，現時点で計算值との相違理由は不明であ る. また，左旋回スタート時の軸心起点位置で実測值 と計算值に違いがあったが，直進状態から旋回が始ま ることを考えれば，計算值の軸心位置は概ね正しいと 思われる.このため，実測值の起点が直進時の軸心位 置と界なっている原因は解明できていない．

本解析は，これまで出来なかった非定常軸彩軸心挙 動一の理解を深め, 大型船推進軸系の信頼性向上に寄 与できると思われるが，大型船旋回時の軸受軸心挙動 解析のツールとしては緒についた段階であり，高周波 変動成分など未解明，末着手の領域へ今後踏み込んで 行く必要がある.

\section{6. 結 論}

船尾管軸受の油膜解析法の検討ならびこ左旋回と右 旋回時の軸心蚧跡計算を実施し、コンテナ船での実測 結果との比較を行い，つぎの結論を得た。

(1) 変動するプロペラフォースを考慮した船尾管軸 受の蟿受油膜解析において, プロペラ軸の軸受支持点 位置と同位置軸撓夕による片当たりを未知数として Newton-Raphson 法による新しい連成解析法を示した.

(2) 時刻昰で変動寸るプロペラフォースを使用して， 様々な船の運航状態の内，船尾管軸受にとつて最も油 膜厚さが薄くなり損傷の危険性が高い過酷な連続最大 出力での操舵角士 35 度条件で油膜計算を行い，コン テナ船での軸心蚧跡実測值結果と比較し，概ね 致寸 る結果が得られ，本解析法の有效性が確認できた。

\section{文献}

(1) Asanabe, S, Akahoshi, M, and Asai, R, Thecretical and Experimental Investigation of Misaligned Journal Bearing Peformance, I Mech E Thbabgy Convention Paper No. C3671,(1971-12)

(2) Oma, T, Asanabe, S, and Washimi, R, Caloulation Method of Shatt Alignment in Relation to OI Film Formation on Stern Tube Bearings, Mitsubashi Heavy Industries, Itd Technical Review, Vd. 12 No.1,(1975) ,pp.85-92

(3) Saitch, T, Dynamic Alignment Thking Acoount of Propeller Forres and Stern Tube Bearing Peformanoes, cbunnal of MESS, Vd18, Na2 (1983), pp. 142-153

(4) Mitsid, J.andAkutsu, Y, AnalysisofShatt Alignment Taking O1 Film Characteristios of Stern Tube BearingintoConsideration, Bulletinof JSME, Vol.27, No.224,(1984), pp. 317-224

(5) Maurelatos, Z P, Parsons, M.G, Finite-Element Analysis of Elastahydrodynamic Sterm Bearings, The Saciety of Naval Architects and Marine Engineers, Annual Meeting November 13-16, (1985)pp. 1-30

(6) Saki, K, Ong, T, Fukutomi, M, Takahashi, B, Koda, M, and Araki, K, Investigation of Stem Pain Bearings for Contra-Rotating Propeller System (3rilRepart, Calculation Method of Shaft Alignment for CRP and Measurement of Inner Shaft Bearing

Peformance of Full-Scale Ship) Transations of the Japan SocidyofMechanical Engineers, Series $C$, Vol, 62 No 597 , (19965), pp.1943-1950

(7) Karni, Z H, Parsons M. G, Time-Varying Lateral Motion of a Marine Shafting System Due to Propeller Excitation, The Socity of Naval Anchitocts and Marine Engineess, Spring MeetingSTARSymposium May 2730,(1987)pp. 1940

(8) Kumaiwa, R, Oshima, A, Nishioka, T, Thteishi, T, Ohyama, $\mathrm{K}$, Ishijma, $\mathrm{T}$, Reliability Improvement of Stem Tube Bearing Considering Propeller Shatt Fones duning Ship Turning , Mitsubrishi Heavy Industries, Ltd Technical Review Vol 44, $\mathrm{Na} 3,(2007), \mathrm{pp} 1 \mathrm{-3}$

(9) Saki, K, Asanabe, S, Takahshi, S, Takahashi, B, Ohta, T, and Ohmura, T, Investigation of SternPlain Bearings forCantra-RotatingPropeler System (4rd Repart, Design of Stem Bearings for Lange Ships and Application to a Very Large Crude Oil Camier) Transactions of the Japan Saciety of Mechancal Engmeans Series $C$, Vol.62, Na 598,(19966), pp23742381 